\title{
The Essence Strengthening the Role of Women Politicians in Local Parliaments the Realization of Gender Responsive Regional Regulations
}

\author{
Said Sampara ${ }^{1}$, Syamsuddin Pasamai ${ }^{2}$, Hamza Baharuddin ${ }^{3}$, Asia $^{4}$ \\ ${ }^{1,2,3}$ Faculty of Law,Muslim University of Indonesia \\ ${ }^{4}$ Doctoral Student of Law, Muslim University of Indonesia
}

Abstract : Based on the description above background further study was made to see how the function of legislative strengthening women by finding models and forms of reinforcement needed in childbirth Gender Responsive Local Regulation. The method used in this study is a combination of normative and empirical research methods, the approach is sociological and juridical, and tended to use the analysis is qualitative. Strengthening the role of women politicians in the Legislative Council on 5 (five) Regency / City still not optimally done either at the level of political parties, Parliament and the internal side of the women's individual legislators in increasing capacity and develop themselves. It became one of the factors in addition to culture patriarkhy, budgets and policies both internal MD3 and Parliament. Supposed to provide reinforcement in addition to the functions and powers of Parliament as contained in Act No. 17 of 2014 on MD3, especially as regards the legislative function which will discuss and establish a Regional Regulation (Perda) Gender Responsive. The number of women in the legislature did not provide assurance that the Regional Regulation born to be gender responsive, but with a debriefing and a good understanding of the legislation and gender issues coupled with at least $30 \%$ of women will certainly give birth gender responsive policy at regional level.

$\begin{array}{lcc}\text { Keywords: } & \text { Women Politicians, } & \text { Regional } \\ \text { Parliament } & \text { (DPRD), } & \text { Regional } \\ \text { Regulations,Responsive } & \end{array}$

\section{Introduction}

The world community is now aware that women should participate in politics because they believe that women will carry the agenda and issues and their own leadership style in politics.Priorities and the different male and female leadership styles will be able to meet at one point at the time when both integrate in political tasks related to the State and society with unique combination because of the differences they have. ${ }^{i}$ Even in the modern era, it can be said that a country is very relevant and ideal if all series of state activities are based on clear legal mechanism. ${ }^{\text {ii }}$

Women as citizens of course have rights as regulated in the Articlesabove. The provisions contained in the Constitution of 1945 is general principle that is used as the basis for the implementation of existing legislation in Indonesia in outlining the equality principle of men and

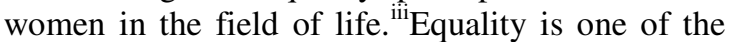
principles contained in democratic life. All citizens have the same rights without distinction of status, social structure or other exclusive identity. ${ }^{\text {iv }}$ One of the fundamental aspects of national development is political participation. A study conductedby the United National Development Program showed that the analytical framework of the relationship between women's political participation and good governance also provided some examples where the provision of opportunities for women in decision-making had improved the welfare of societyoverall. ${ }^{v}$

The provisions on the nomination of women at least $30 \%$ of the candidate list of legislative candidatesof each party in the provisions of Law Number 12 of 2003on General Election had been deleted and replaced Law No. 8 of 2011 on General Election of Members of Parliament (DPR), Regional Representative Council(DPD) and Regional Parliament(DPRD).The election results of 2004 showed that elected members of Parliament (DPR) of the Republic of Indonesia included 11.8\% of women from the total number of members. This was increase from the number of female legislative members election results in 1999 which was only $9 \%$.

Ahead of the General Election of 2009, affirmative policy was strengthened by the provisions of Law Number 2 of 2008 on Political Parties that had been deleted and replaced by Law Number 2 of 2011 on Political Parties, concerning the minimum number of $30 \%$ of women in the stewardship.The affirmation policy in the Election Law was also reinforced by the placement of women legislative candidates as well as with the provisions in three candidate names there were one female name (Law No. 10/2008). As a result, the number of women in the legislature at the National level increased to 
$18 \%$ of the total members of Parliament (DPR) of the Republic of Indonesia. This increase could be said to be significant although still far below the critical $30 \%$.

Efforts to increase the role of women is the development of domestic politics that becomes strategic area for the achievement of gender equality. Before entering the reform era, domestic politics has not changed much.Decision-making and control to development are strongly dominated by men, while women in politics are still very minimal role. Entering the reform era, the encouragement to increase the role of women with men in the political sphere increased. ${ }^{\mathrm{vi}}$

Election of 2009 was also $16 \%$ women members in Regional Parliament (DPRD) at the provincial level and average of $12 \%$ in Regional Parliament(DPRD) of Regency/Municipalitylevel.Studies on the results of election of 2009 and women's representation in the legislature showed that efforts to increase women's representation had not been reached maximally despite increase in the women quantity in the institution.This was indicated by some objective conditions as follows: first, despite the increase in the number of women in Parliament(DPR) and Regional Parliament(DPRD), but women's representation at the local level had not beenspread evenly because there were still a number of Regional Parliamentin regencies/municipalitiesthat had not had female members.Second, affirmative policy was still understood by party administrators limitedof administrative aspects to comply with the provisions of Law, this policy was finally used by party elites to nominate women in their nearest circle, without considering the skill aspect and women's political experienceconcerned.

The next factor was socio-economic. Socioeconomic conditions of the region could also be considered to affect women's representation at the local level. In some provinces with women's representation above the national average, only three regions showed the possibility of relationship betweenthe ranking of good Human Development Indexand the higher number of women's representation.

Reinforcementthe role of women to produce Regional Regulations (Perda) of genderresponsiveis part of affirmative action that needs to be realized immediately. The presence of gender responsive policy is space for women to convey their situation and importance to government so that it can be program or priority policy at Provincial or region level.Until now, there are only some provinces that already have Regional Regulation (Perda) of Gender Mainstreaming that is Banten Province with the Regional Regulation Number 10 of 2005, and Governor Regulation Number 39 of 2006 on Guideline of Action Plan of
Gender Mainstreaming Region of Banten which had got Award of Parahita Award Ekapraya from President Susilo Bambang Yudoyono with progressive policy.

South Sulawesi Province had also discussed and ratified the Regional Regulation of Gender Mainstreaming which would be discussed with Regional Parliament (DPRD) in 2015.And some Regencies/Municipalitiesincluding areas that would be the focus of research had also discussed and ratified the Regional Regulation on Gender Mainstreaming. The importance of accelerating the adoption of Regional Regulations on Gender Mainstreaming in South Sulawesi Province,so that policies that have been discriminatory against women and other vulnerable groups are no longer done, as well as various regulations that are genderbiased or discriminatory against women can be revoked or canceled.

Efforts for witdrawl of discriminatory policies of women is not only the work of the people, especially women in monitoring the discriminatory policies, but also involving Executive and Legislative eitherProvincial orRegency/Municipalitydomain to open the dialogue space and discuss the discriminatory policies. The existence of discriminatory policies in a region showed that the government's political will in providing protection, fulfillment and respect of human rights every individual society including women had not been fully understood.

Indonesian legal politics in gender perspective still needs to be improved, because there are still many Legislation that have not been gender perspective. ${ }^{\text {vii }}$ The fact is the development of the current Indonesian Constitutional, continuously by juridical complements the legislation that will regulate all the things that become the needs of society and the Nation of Indonesia.Meanwhile, the flow of change desired by communities is very strong, especially to the product of responsive legislation and sustainable, especially responsive to the situation of women and marginal communities.Basically, the people want the public spaces that allow the voice of the people/women can be accommodated and discussed in the preparation of the substance of legislation. In this context, we look at theGender Responsive Regional Regulations Scale.

The power or authority of central government is generally defined in the Constitution of the Republic of Indonesia of 1945, whereas the power and/or authorities of regional government are included in the establishment of legal products established by the central legislature.Furthermore, in Article 8 Paragraph (1) of the Constitution of 1945 after the amendment stated that the Unitary State of Indonsia is divided into the Provinciesand the Provinciesare divided into 
Regencies/Municipalities having Regional Government regulated by Law. The use of the term is divided into provinces and the provinciesare divided into Regencies/Municipalities intended to affirm the relationship between Central and Regional Government. Within the vast territory of country such as Indonesia, it is impossible for all State affairs to be solved by means of completeness which are domiciled only in Jakarta (Centralized).Juanda said that the regional government covers all State completeness that are not functioning as tool of the central government. This means that "the center is connected with its function in the central office, which is the authority covering all areas of the State, while the authority of the regional government covers only a part of the territory of the State".

These wishes and desire, of course do not rule out the existence of the people'srepresentatives inRegional Parliament(DPRD).Need for continuity of role between community and Regional Parliament (DPRD), because in fact the people's representatives who are on the council cannot represent all the aspirations ofsociety which are very dynamic.We can see also that some policies that are born thus far from the expectations of society, especially policies that discriminate against women and other vulnerable groups.

The increasing the number of women in Regional Parliament (DPRD) was not immediately giving birth to policies that were responsive to the situation and needs of women. This was due in part to the understanding and capability of female council members who had not fully understood and involved women and vulnerable groups in the community in formulating the draft Regional Regulations. (Sirajuddin; 2006:119)described the urgency of community participation in the formulation of Regional Regulations: Capturing knowledge, expertise, or community experience so that the Regional Regulations were made really qualified for good Regional Regulations.Ensure Regional Regulationsin accordance with the reality in the community, foster sense of belonging, sense of responsibility, and sense of accountability of the Regional Regulations.

From the explanationabove, it appeared that the drafting of legislation including Regional Regulations taking place within certain social structures and this was part of larger social process.Departing from this perspective, then the drafting of legislation did not automatically run smoothly, when the social structure in which the making undemocratic, in other words very dependent of government conditions, stakeholders and the people.

\section{Discussion}

\section{A. Strengthening Models are Needed in Encouraging Gender Responsive Regional Regulations}

Since the last few years, the word gender has entered the treasury in every discussion and writings about social change and development in the third world. Similarly, in Indonesia, almost all the descriptions of community development programs as well as developments among NonGovernmental Organizations are discussed about gender issues.Gender differences often lead to injustice, one of which causes subordination to women. The existence of assumption that women are irrational or emotional so that women are not able to appear leading to the emergence of attitudes that put women in positions that are not important. $^{\text {viii }}$

Previous research results had shown that female council members had been involved in the drafting of legal products in the regions, but that did not guarantee that their existence was "equal" with male legislators.In fact, the existence of female legislators was still regarded as complementary tool/accessories only. This was because the role of each member of the (women's) council had not yet been active in providing input. The reasons for their inactivity in the manufacture of legal products were: First,because the council members were women. Second, because the members of the council were minority. Third, because of the assumption that women were not capable, so often the input given less addressed wisely.The consequences of these three aspects had an impact on the low involvement of women in providing input and arguments for legal products. ${ }^{\mathrm{ix}}$

Women did not talk much in court. Second, political education conducted by the political parties did not distinguish between legislative candidates of female and male, whereas the needs and challenges faced by male and female candidates were different.Third, the cynical attitude of male legislative toward the proposed women's program also hampers the courage of women legislators to voice the women interests.Although not all male legislators acted like this, cynical and mocking voice made women legislators reluctant to submits suggestions, especially those relating to the issue of women and other vulnerable groups.Fourth, the lack of quality and ability of female members in conveying ideas. Moreover, the number of female members were too small thanmale. As a result, women's voices were not heard in sessions. The issue of the personal qualities of women legislators in submitting proposals was an important factor that determines whether male members would support the proposals of female members or not.Fifth, lack of confidence among women legislators. In parliament the dominance of male members seems very dominant. They dare to 
speak loudly and assertive, although not infrequently the substance of the conversation was not directional. Such hard and assertiveattitudes were not shared by women legislators, so in the midst of legislative sessionstheir votes tend to drown, even choosing not to say much.Sixth, lack of understanding of women's issues. Most women legislators had not fully understood that one of their tasks was to fight for women'sinterests. The lack of understanding was one of the reasons for the inadequacy of women's interest in Regional

Table 1

Legislative Candidate Comparison of Female and Male on ResearchSite

\begin{tabular}{|c|l|c|c|c|}
\hline & Regency/Municipality & Number of Seats & Female & Male \\
\hline 1 & Bone & 45 & 6 & 39 \\
\hline 2 & Maros & 35 & 7 & 27 \\
\hline 3 & Bantaeng & 25 & 11 & 14 \\
\hline 4 & Pare-Pare & 25 & 3 & 22 \\
\hline 5 & Makassar & 50 & 8 & 42 \\
\hline & Total & 180 & 35 & 144 \\
\hline
\end{tabular}

Source: Electoral Commission Regency/Municipality 2016

From the table above showed that the number of male in Parliament more than female. Although the educational backgrounds of female legislators were mostly high school and scholar, but political experience, political education and understanding of women issues had not yet been addressed, even most did not understand the issues of women, children, the poor and the difable.

Therefore, it is necessary to formulate strategies and models to strengthen the political capacity of female legislators, so that they can develop the function as voices and women's interest advocates. In examining the situation of some models of political education for women haveever done by some women's organizations in strengthening the political capacity of women legislators.

Political parties are one of the agents that have responsibility to undertake political education.However, not all political parties carry out the function of political education with intense, especially small parties or new political parties.Most political parties do political education for elected candidates either male orfemale together.Nevertheless, women elected party candidates will usually work with NonGovernmental Organization or invite discussion of activists who are interested in women's empowerment programs by sending women legislators for training.

Some of the parties joined in the the Parliamentary Women's Caucus conducted political education for female members in cooperation with IRI. One of the materials that had been given about election winning strategies and understanding specific issues related to women including in carrying out
Parliament (DPRD).Seventh, most women legislators had not used the mass media to raise support and fight for women's interests.Though mass media was one of the important media for women legislative members to voice and fight for women's interest. ${ }^{\mathrm{x}}$

The phenomenon of 'defeating' women legislators along with the factors that caused them little talk in parliamentary sessions illustrates that women's representation solely yet guarantee the fulfillment of women's interests. the legislative function of woman parliamentarians to create gender responsive policies. The members of Regional Parliament (DPRD) of South Sulawesi Provincial, Mrs. Andi Nurhidayati said that before becoming a member of the legislature had been become party cadre long enough and gathered with the activists in her region.Capacity building was being provided not only from IRI but also women's organizations that continue to encourage women's representation in legislatures, such as the South Sulawesi Women's Electoral Forum (FPMP-SS) and Indonesian Women's Coalition (KPI).Although Mrs. Andi Nurhayati said that: "it is urgently needed political education especially for women legislators because women have no experience as men in politics... so political education is the absolute thing to be done by political parties..."

One member of the women legislators, Mrs. Andi Nurhanjayani fromRegional Parliament of ParePare, said that "I had attended some briefings either by parties or women's NGOs in Pare-pare or Makassar, such briefings was very beneficial to me, even though I was woman activist and also a former member of the General Election Commission (KPU Pare-pare), but political education or briefing was very important to me, as well as male legislativecandidates and female legislative candidates."Further Mrs. Andi Anja (nickname Andi Nurhanjayani) said that women should go forward and the one that makes women go forward is experience. I was originally an ordinary Housewife, but because of organization and passion to learn more so I can be like this. This is my second period in the Legislature and never in my policy discussions or my budget is excluded 
and constantly pushing the interests of women in it". (Interview with Andi Nurhanjayani, September 2016).

Mrs. Andi Anja's experience, in line with that expressed by Bantaeng Regent: "Thestrengthening of women in the State institutions is very important, why? Since women in legislature are the representatives of the community, if their capacity and education cannot lead them to voice the public interest, then there are things that need to be addressed in our political education.In Bantaeng Regency has exceeded the quota of $30 \%$, but not only $30 \%$ of which are pursued then completed, thus after being electedthe women's struggle just started. Political parties play an important role in enhancing women's capacity, not only think about how their cadres can sit in legislature, but how the cadres sit in contributing thoughts to development and development of resources in the region (Interview with Bantaeng Regent Prof. Nurdin Abdullah).

Since the quota of $30 \%$ of women's representation inthe elections of 2004, various organizations conduct briefing on women legislative candidates. This effort reflects how persistent women voice and encourage their interests in decision-making institutions at the country level. However, the hard effort has not been offset by the strength of women themselves to get into politics, willing to be legislative candidates and compete with men.From the statements of some political party functionaries who later became women legislators it wasseen that political parties had less concern for the needs of women politicians. Political parties tend to generalize political briefing materials for their cadres.As a result, the ability of women legislators to be not maximal because they neededdifferent psychological strength with men when in the middle of the majority of the Council members were men. This psychologically strengthening was still escaped from the attention of political parties.

Political Education by Non-Governmental Organization (NGO)other actors who actively and regularly organize political education for women is NGOs. The form of political education conducted by NGOs is very diverse, such as seminars, workshops, leaflet spread, poster placement, training and writing in mass media as well as electronic media.One of NGOs that are intensely conducting political education for women locally is FPMP of South Sulawesi and National level areInternational Republican Institute (IRI) and Indonesian Women's Coalition (KPI).FPMP of South Sulawesi and Indonesian Women's Coalition (KPI) have goals to increase the number of women in the legislature with skills and good knowledge in encouraging women's interests in the legislature, activities undertaken to increase women's awareness of their rights as citizens, enhance women's voters capacity in order to be able to make rational decisions and independent (free from outside pressure), giving insight to women voters about the importance of selecting women's representatives and its implications for changes in women's welfare levels, giving practical knowledge of ballots, voting procedures and voting simulation. While IRI has a goal to develop political development towards a democratic country since the fall of Soeharto regime in 1998. This goal is realized by supporting the process of democratic consolidation in Indonesia through strengthening government institutions, encouraging political parties to better understand voter's will and encouraging the increased participation of women in politics and government (www.iri.org/asia/indonesia.asp).The institution that also actively conducts political education for women legislators is Asia Foundation. This institution hadconducted training which was attended by 182 women legislators of Provincial Regional Parliament and Regencies throughout Indonesia.The material given is about local politics, gender responsive budgeting and legal drafting.

With various experiences above, the researcher sawthat alternative model of political education effort is required for women legislators. The efforts made during this time still has not produced satisfactory fruition. The purpose of political education to make women legislators had adequate capability in carrying out missions as people's representatives of achievement were still not maximized.

Related to the efforts to strengthen political capacity to enable women legislators to have the ability and courage to fight for women's interests, then neededalternative political education model. Material for alternative political education include four issues: (1) identification of women's issues, (2) communication skill and lobbying techniques, (3) improvement of confidence and (4) networking and partnership.These four main subjects are very important to women legislators with the main considerations as follows: first, based on research results in 2007-2008, most of women legislators had not fully understood aboutwomen's issuesthat were supposed to be fighting for.The majority of women legislators who hadfought the women's interests had moved around practical women's issues (e.g. health care of mothers and toddlers, posyandu, provision of capital for women and had not foughtthe women'sinterests that strategic (e.g. violence against women, women's access to politics, involvement in decision-making, or reproduction rights so women had the independence to decide whether to be pregnant or not, what contraceptives to be used and more).Second, most of woman legislators lack the skills to express convincingly in council meetings 
and less shrewd at lobbying with Executive agencies when they had to fight for theconstituents' interests. Therefore, training on communication skills and lobbying techniques indispensable to encourage woman legislators to be able to and dare to express their opinionsconvincingly.Third, most of women legislators,lack confidence when proposing in council meetings. This condition requires special solution that was training to increase confidence. Fourth, some important media thatcouldbe usedby legislators to strengthen persuasion and their existence, such as mass media and women's organizations had not been adequately utilized.

For that understanding of the significanceof building a network is indispensable. Two important materials that are very important to support the main tasks as legislative members are legal drafting and budgeting that need to be the attention of political parties or institutions of Regional Parliament (DPRD).

The same thing was conveyed by Rosniaty Azis, woman activist who facilitated some capacity building for women legislative candidates; "Networking is very important for women who have desire to engage in practical politics, networking will greatly assist women legislative candidate to obtain a lot of information about the needs at the time of the elections until elected to the legislature.Ros furthered that the strengthening model needed by the most important woman legislators are legal drafting and budgeting that will assist female legislators in making genderresponsive or pro-gender responsive policies".

As it is known that PUG is a strategy, not a goal. This strategy is formulated to design, implement, monitor and evaluate policies and programs throughout the political, economic, social, and culture can be realized. While the main goal is to realize gender justice.With PUG then all development programs can be implemented taking into account opportunities and women's access to development programs, and with the control and benefits for women.

In Indonesia, PUG is officially adopted into development strategy women empowerment field through Presidential InstructionNumber 9 of 2000 on Gender Equality in National Development.In Presidential Instruction stated that the purpose of PUG is the implementation of planning, compilation, implementation, monitoring, and evaluation on policies and programs of national development with gender perspective. And PUG strategy taken in order to realize gender equality and justice in family life, community, Nation, and State.

Chart 1

Gender Mainstreaming Indicators

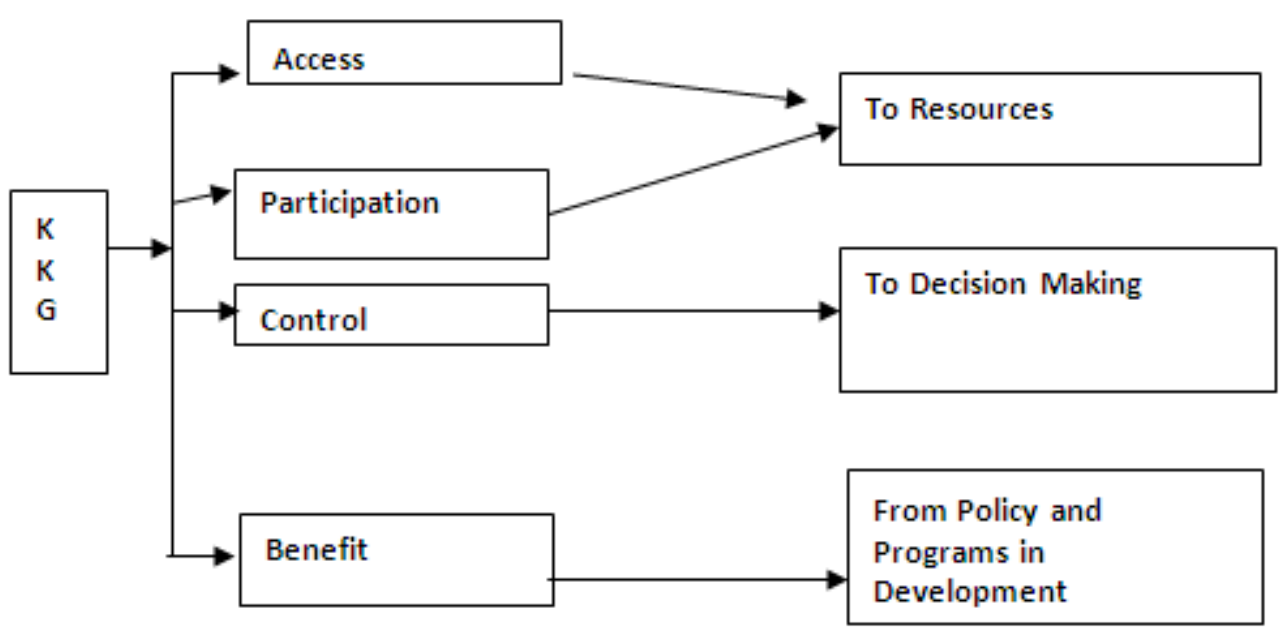

Data Source: Ministry of Women Empowerment and Child Protection (KPPPA) of 2010

The chart above showed that women had the rights to gain access and participation to resources, that women had the rights to control all decisionmaking in various damains/levels and should benefit from the policy and development programs made by Government.
In realizing PUG, of course has prerequisite that requires seriousness and real commitment from the parties, the prerequisites of implementating PUG are the commitment of politicians, policies, institutions, resources consisting of human resources, facilities and funds, data and information disaggregated, instrumentsthat can facilitate the 
achievement of PUG by strengthening the analytical method, preparing guidelines, operational guidelines,technical guidelines andthe important ting is how the role of community in controlling and evaluating the policies and development programs planned by Government.

\section{B. Women's Challenges in Encouraging Gender Responsive Policy}

The main challenge of women in legislature in encouraging gender responsive policy is the patriarchal culture that still strengthens in the minds and attitudes of legislators, especially male legislators. With these patriarchal views, there will be many reasons to disagree with the policyor gender-responsive development programs, including providing space and the same opportunity to women legislators to occupy strategic positions in the legislature, for example as leaders of Regional Parliament (DPRD)so women have the opportunity to lead sessions and can take decisions that voice/profitable the interests of vulnerable groups.

Should the opportunity to become the leaderof Regional Parliament (DPRD)can be open and accessible to all members of legislature, but sometimes the interests and strength of political parties that 'in power' with the largest amount not to mention almost all party's leaders controlled by men, so in the process of determining the leadership in Regional Parliament is still more likely to give men the opportunity to become leaders.

Specifically, in Law Number 17 of 2014 on the People's Consultative Assembly (MPR), Parliament (DPR), Regional Representative Council(DPD), and Regional Parliament (DPRD), in the third section discussing the authority and duties of Regency/MunicipalityRegional Parliament (Article 366) clearly stated that Regional Parliament's authority,as follows; (1) Regency/Municipal Regional Parliamenthas authorities and duties: (a) Establishing Regency/Municipal regulations together with Regent/Mayor; (b) Discusses and approves the draft Regional Regulations on Regional Government Budget Regency/Municipalitysubmitted by Regent/Mayor;(c) Carrying out supervision on the implementation of regional regulations and Regional Government Budget Regency/Municipality; (d) Propose the appointment and dismissal of Regent/Mayor and/or Deputy Regent/Deputy Mayor to the Minister of Domestic Affairs through Governor for approval of appointment and/or dismissal;(e) Electing the Deputy Regent/Deputy Mayor in the event of vacancy positionofDeputy Regent/Deputy Mayor;(f) Provide opinions and considerations to Regional GovernmentRegency/Municipalityon
International agreements plans in region;(g). Give the approvalon International cooperation plans undertaken by Regional GovernmentRegency/Municipality;(h) Request the report description accountability of Regent/Mayor in the implementation of RegionalGovernment of Regency/Municipality; (i) Give the approval to cooperation plans with other regions or with third parties that burden the community and the region; (j)Strive for the implementation of regional obligations in accordance with the provisions of legislation; and (k) Implementthe authorityand other duties regulated in the provisions of legislation.

The legislationmentioned above is reference to Regional Parliament(DPRD) in exercising their authority and functions in accordance with Article 365 of Law Number 17 of 2014. Therefore, Regional Parliamentis the main key in realizing the policy in the form ofGenderResponsive Regional Regulation, of course by understanding four indicators has been written in the previous section of Access, participation, control and benefits.

Based on the results of research by using indept interview method to some legislative member of woman and man, found that; Legislative members still had minimal understanding of the function of legislation and specifically gender understanding. This lack of understanding affects policy or development and the policies discussed or decided were still biased and gender-neutral. To provide an understanding of bias and gender neutrality could be seen in the following sense;(1) Gender-biased planning is planning that leads to the interests of either male or female. (2) Gender-neutral planning is without considering to aspirations/needs of men and women, and (3) Gender-responsive planning is to consider the needs, aspirations of men and women.

One of the speaker former members of the legislative of Bantaeng Regency (Nurdin, S.Ag) said that in establishing a policy or legalizing the government program impressed that women legislators were only involved quantitatively, only seeing that there were representatives of women legislators involved in the discussion and ratification of policies and government program budgets.But in understanding the substance through giving opinion to the policy documents was discussed, there was no visible significant contribution from women legislators. Furthermore, Nurdin expressed that women legislators should be very important to have capacity especially related to gender, legislative function, budgeting and supervision as regulated in Law no. 17 of 2014, so that in carrying out the functions and authority of women legislators had concepts and thoughts that represent women in parliament, in this case to 
voice the situation of women and other groups in society.One of the factors that caused women legislators to lack understanding of the function of legislative members was the educational and occupational background, although it was not a barrier for women in the legislature to understand the various aspects required by a legislator, but the willpower of the woman Itself to learn things that during this political did not become an interesting thing to learn by women.

Furthermore, it was conveyed that it still had a lot of things that must be addressed by Regional Parliamentinstitutionally, as well as Political Parties in increasing the capacity of women legislators, not an easy task to change women's maindset of gender constructions in society.Therefore, it was needed commitment and seriousness both personally, legislature of Regional Parliamentand the Party in enhancing the knowledge and skills of women legislators so as to be competent with other legislative members in Regional Parliamentwhich certainly represents the expectations of women who support it or in general women and society in the region.

The same things was also conveyed by Husaimah Husain that increasing the capacity building of women legislative members should be built not only on legislative members, but the most important political parties and Regional Parliamentinstitutionally. If these two things were maximized then women legislators would be directly motivated to increase their capacity in relation to various issues that occur in the community/constituency.So, in the future, society will be more confident that women legislators in parliament have sensitivity and gender analysis in seeing various social phenomenon happened or experienced by woman in particular.

One of the functions of legislature is to analyze and discuss government planning. If femaleand malelegislatorsdo not understand genderresponsive planning then the established planning will not have significant impact on the community especially vulnerable groups, including women.

In theory of gender responsive planning, there are 4 (four) things that should be of concern, namely; (1) Participatory planning taking into account four aspects of access, participation, control and equal benefits for men and women. (2) Integrating the aspirations, needs, issues of men and women into men and women's issues into planning (PUG). (3) Based on the results of gender analysis using gender disaggregated data/statistic gender (GAP), and (4) The action program is aimed at addressing gender issues/gender disparities.

The four points above are the key for legislative members in policy development and gender responsive programs. The need for gender responsive policy is urgent because with gender responsive policy, then gender injustice treatments are (1) Discriminative, (2) Sterio typing/labeling, (3) Sub-ordination (4) Marginalization, will not happen.

The various situations of injustice above are challenges for women legislatures to ensure that all legal products are issued equally to women and other marginalized groups. Of course, these challenges can be minimized with good knowledge and skill on issues or issues related to women.Indeed, there has been a lot of the space for women legislatures to increase their knowledge and skills in carrying out their functions and understanding issues concerning women and vulnerable groups, but returning to the willingness of women legislators learning and taking the time to understand and explore it so that the regional policies discussed and endorsed gender responsive.

\section{Conclusion}

The strengthening model for women legislators other than women legislators should have the same powers as male legislators with knowledge and opening up to dialogue with various parties such as academics, women activists, civil society organizations that have concerns about the issues of women and society (Constituents), especially women, so that women legislative members not only have the theory but also the empirical facts experienced directly by women. By having empirical data and reinforced by theories it has, it can be ensured that the policies discussed either by government initiatives or legislative initiatives will ensure the fulfillment of human rights by establishing fair policy and gender responsive at the regional level.

\section{Bibliography}

Nurwani Idris, Perempuan Minangkabau Dalam Poltiik, Jurnal Humaniora, Volume 2, Nomor 2, Juni 2010.

Ayu Putu Nantri, Perempuan dan Politik, Jurnal Studi Gender Srikandi, Volume 3, Nomor 1, Januari 2003.

Dewi, MA \& Ilkodar, SB,(2008).Implikasi Peningkatan Keterwakilan Perempuan bagi Pemenuhan Kepentingan Perempuan (Studi pada DPRD Provinsi DIY). Surabaya: Masyarakat, Kebudayaan dan Politik 21(1)

Hardianto Djanggih and Kamri Ahmad, The Effectiveness of Indonesian National Police Function on Banggai Regency Police Investigation (Investigation Case Study Year 2008-2016), Jurnal Dinamika Hukum, Volume 17, Nomor 2, 2017. 
Janpatar Simamora, "Tafsir Negara Hukum dalam Perspektif Undang-Undang Dasar Negara Republik Indonesia Tahun 1945", Jurnal Dinamika Hukum, Vol., 14 Number 3, September 2014, Purwokerto: Faculty of Law Jenderal Soedirman University.

Tri Lisiani P, Perspektif Gender Terhadap Putusan Mahkamah Konstitusi Tentang Dihapuskannya Kebijakan Afirmatif Perempuan Di Parlemen Pada Pemilu Tahun 2009, Jurnal Dinamika Hukum , Volume 10, Nomor 2, Mei 2010.

Ani Purwanti, Partisipasi Perempuan Pada Lembaga Legislatif Tahun 2014-2019 Di Provinsi Jawa Timur, Jurnal Masalah-Masalah Hukum, Volume 44, Nomor 2, April 2015.

Siti Nurul Khaerani, Strategi Meningkatkan Kesetaraan Gender Dalam Bidang Politik Di Nusa Tenggara Barat, Jurnal Qawwam, Volume 8, Nomor 1, 2014.

Dessy Artina, Politik Hukum Kesetaraan Gender Di Indonesia, Jurnal Ilmu Hukum, Volume 1, Nomor 1, 2010.

Ayu Putu Nantri, Kajian Terhadap UU Politik dan Perspektif Gender, Jurnal Studi Gender, Volume 6, Nomo1, 2007.

Riris Ardhanariswari, et.all, Keterlibatan Perempuan Dalam Penyusunan Produk Hukum Daerah Kabupaten Bayumas, Jurnal Dinamika Hukum, Volume 8, Nomor 1, 2008, hlm.58-59

Nurwani Idris, Perempuan Minangkabau Dalam Poltiik, Jurnal Humaniora, Volume 2, Nomor 2, Juni 2010, hlm.165

ii Janpatar Simamora, "Tafsir Negara Hukum dalam Perspektif Undang-Undang Dasar Negara Republik Indonesia Tahun 1945", Jurnal Dinamika Hukum, Vol., 14 Number 3, September 2014, Purwokerto: Faculty of Law Jenderal Soedirman University, page. 548, see to Hardianto Djanggih and Kamri Ahmad, The Effentiviness of Indonesian National Police of Investigation Function in Banggai Regency Police (Investigation Case Year 2008-2016, Jurnal Dinamika Hukum, Volume 17, Nomor 2, 2017, hlm.152

iii Ayu Putu Nantri, Perempuan dan Politik, Jurnal Studi Gender Srikandi, Volume 3, Nomor 1, Januari 2003, hlm.5

iv Tri Lisiani P, Perspektif Gender Terhadap Putusan Mahkamah Konstitusi Tentang Dihapuskannya Kebijakan Afirmatif Perempuan Di Parlemen Pada Pemilu Tahun 2009, Jurnal Dinamika Hukum , Volume 10, Nomor 2, Mei 2010, hlm.157

$\checkmark$ Ani Purwanti, Partisipasi Perempuan Pada Lembaga Legislatif Tahun 2014-2019 Di Provinsi Jawa Timur, Jurnal Masalah-Masalah Hukum, Volume 44, Nomor 2, April 2015, hlm.192

vi Siti Nurul Khaerani, Strategi Meningkatkan Kesetaraan Gender Dalam Bidang Politik Di Nusa
Tenggara Barat, Jurnal Qawwam, Volume 8, Nomor 1, 2014, hlm.134

vii Dessy Artina, Politik Hukum Kesetaraan Gender Di Indonesia, Jurnal Ilmu Hukum, Volume 1, Nomor 1, 2010, hlm.64

viii Ayu Putu Nantri, Kajian Terhadap UU Politik dan Perspektif Gender, Jurnal Studi Gender, Volume 6, Nomo1, 2007, hlm.1-2

ix Riris Ardhanariswari, et.all, Keterlibatan Perempuan Dalam Penyusunan Produk Hukum Daerah Kabupaten Bayumas, Jurnal Dinamika Hukum, Volume 8, Nomor 1, 2008, hlm.58-59

x Dewi, MA \& Ilkodar, SB, (2008).Implikasi Peningkatan Keterwakilan Perempuan bagi Pemenuhan Kepentingan Perempuan (Studi pada DPRD Provinsi DIY). Surabaya: Masyarakat, Kebudayaan dan Politik 21(1) 